\title{
DEVELOPMENT PROSPECTS OF MILK PRODUCTION IN VARIOUS SIZE FARM GROUPS IN LATVIA
}

\author{
Irina Pilvere $^{1}$, Aleksejs Nipers ${ }^{1}$, Agnese Krievina ${ }^{2}$, Ilze Upite ${ }^{1}$ \\ ${ }^{1}$ Latvia University of Life Sciences and Technologies, Latvia; \\ ${ }^{2}$ Institute of Agricultural Resources and Economics, Latvia \\ irina.pilvere@1lu.lv, aleksejs.nipers@1lu.lv, agnese.krievina@arei.lv, ilze.upite@1lu.lv
}

\begin{abstract}
World population growth will increase the demand for food, while rising incomes are expected to change the eating habits. Agriculture remains a major source of nutrients that may require drastic changes. Accordingly, it is necessary to project the potential future development of various agricultural sectors. Therefore, the overall aim of this study is to identify the development opportunities for dairy farms of various sizes in Latvia until 2050. In the period 2005-2018, Latvia experienced significant structural changes in dairy farming, as the production of cow's milk and the sales of it for processing increased, while the numbers of dairy cows and dairy farms decreased significantly owing to the disappearance of small dairy farms (up to 5 cows). For this reason, it is required to project the future development of dairy farming. To generate projections for agricultural production in Latvia until 2050, the Latvian Agricultural Sector Analysis Model (LASAM) was developed at the Latvia University of Life Sciences and Technologies in 2016. Within this research project, the LASAM model was extended by a module for the distribution of farms by size. According to the projection generated by the LASAM model, the milk production in Latvia is expected to gradually increase to 1196.1 thou. $t$ by 2050 , while the number of dairy cows is expected to gradually decrease to 119.6 thou. (-17 \% compared with 2018), which is determined by production intensification in dairy farming and expansion of large farms with more than 300 cows.
\end{abstract}

Keywords: agriculture, simulation, dairy farm size groups.

\section{Introduction}

The growth of the world population will continue throughout the $21^{\text {st }}$ century. This requires food production and distribution to match the needs of the increasing number of people [1]. Agriculture remains a major source of nutrients that may require drastic changes [2]. However, food is not a simple, aggregate commodity, and the composition of world food demand has been changing dramatically over the last two decades, much of this itself fuelled by income growth [3]. Therefore, many research studies perform economic modelling, including for agriculture, to identify potential scenarios for development. For example, a research study by J. Helina and H.P. Weikard “...focuses on the role of phosphorus, an essential (non-substitutable) nutrient for all primary food production" [1]. O. Galor and D.N. Weil (2019) “... developed a unified growth model that captures the historical evolution of population, technology, and output. It encompasses the endogenous transition between three regimes that have characterized economic development" [4]. A. Bartosova, R. Capell, J.E. Olesen, et al. (2019) "compare results from dynamic modelling of nutrient loads to the Baltic Sea under projections of climate change and scenarios for shared socioeconomic pathways" [2]. I. Odegard and E. van der Voet (2014) point out that "We do not have the resource base to supply current Western diets globally in 2050..." [5]. Similar research has been done by F. Duchin (2005) [6], S. Nonhebel (2004) [7], W. Yu, T.W. Hertel, P.V. Preckel et al. (2003) [8], B. Jones and B.C. O’Neill (2016) [9], P. Meiyappan, M. Dalton, B.C. O'Neill et al. (2014) [10] and others.

Agriculture is an important sector of Latvian economy. Despite the fact that its share in total value added was only $1.6 \%$ in 2018, the average number of employed in the age group from 15 to 74 was 63.3 thousand or $4.9 \%$ of the total number of employed persons, and agricultural, food and fishery products accounted for $20 \%$ of the total value of exports. In 2018, the share of milk and meat production in the total final agricultural output was $28.3 \%$ - only $0.5 \%$ below that of grain production [11]. For this reason, the development of agriculture in Latvia will be determined by these two sectors, and therefore it is important to project the trends of dairy farming. Similar research studies are being conducted in other countries, because, as emphasized by the OECD, "the next 50 years will see major changes in the composition of the world economy. In the absence of ambitious policy changes, global imbalances will emerge which could undermine growth" [12]. Livestock farms are an important source of ammonia emissions [13]; therefore, the future development of sustainable livestock farming has to seek possibilities to reduce the negative impacts of climate change. J. Helin (2014) stresses that "Growth trends of animal farming pose a threat to water quality around the world. 
To find cost-efficient means to reduce nutrient loads from agriculture, detailed information on the abatement measures need to be incorporated in bioeconomic models" [14]. P. Gerbens-Leenes, S. Nonhebel, M. Krol (2010) have analysed "relationships between food supply, consumption and income, taking supply, meat and dairy, and consumption composition (in macronutrients) as indicators, with annual per capita GDP as the indicator for income. For low income countries, GDP increase is accompanied by changes towards food consumption patterns with large gaps between supply and actual consumption. People in high income countries derive nutritional energy mainly from carbohydrates and fat, with substantial contribution of meat and dairy" [15].

Therefore, the overall aim of the research is to identify development opportunities for dairy farms of various sizes in Latvia until 2050.

\section{Materials and methods}

To generate projections for the Latvian agricultural sector, the LASAM model was developed in 2016. The model covers the following key agricultural sectors: cereals (wheat, barley, rye, oats, triticale), oil crops (rapeseed), legumes, potatoes, vegetables, dairy and beef cattle, sheep, goats, horses, pigs, poultry [16-18]. The model initially was developed as an econometric, recursive, dynamic, multi-period scenario model. Those projections were primary focused on "activity data" (agricultural areas, numbers of animals) and used to estimate agricultural production in Latvia and agricultural GHG emissions. Within this research project, the LASAM model was extended by a module for creating distribution of farms by size for the most important agricultural industries in Latvia. One of the industries is dairy farming. The distribution of farms is needed to link the projections made with the GHG emission measures that have been designed for farm clusters grouped by specialization and size [19].

The calculations and projections for the period until 2050 largely rely on the Farm Accountancy Data Network (FADN) data [20]. The model is written in R language, using RStudio software.

Cow's milk production. The model generated a projection of milk production in Latvia based on individual projections of milk sales (i.e milk deliveries to processing enterprises), milk consumption on farms by family and milk consumption on farms as animal feed:

$$
\text { cowmi_tton_pr }=\text { cowmi_sale_tton_pr }+ \text { cowmi_cons_tton_pr + cowmiffeed_tton_pr }
$$

where cowmi_tton_pr-total milk production projected;

cowmi_sale_tton_pr - projected quantity of milk for sale (milk deliveries);

cowmi_cons_tton_pr - projected quantity of milk for human consumption on farms;

cowmi_feed_tton_pr - projected quantity of milk for livestock consumption on farms.

Cow's milk sales. The key driver of milk production is the commercial sales of milk, which is affected by a number of factors. The model allows projecting annual percentage change in milk sales (i.e. milk deliveries), assuming the milk price and support payments to be the main factors in production expansion, as well as production costs that are combined into a ratio of revenue to expense for milk production:

$$
\text { incost_coef_cowmi }<-(\text { cowmi_price }+ \text { supp_cowmi_ton }) / \text { cowmi_cost_ton }
$$

where incost_coef_cowmi - ratio of revenue to expense for milk production; cowmi_price - milk purchase price;

supp_cowmi_ton - support payments per tonne of milk produced; cowmi_cost_ton - production cost of a tonne of milk.

A projection of annual change in milk sales is derived from a regression equation, in which a ratio of revenue to expense for milk production is a predictor variable:

$$
\text { cowmi_sale_tton_gr_reg }<-l m(\text { cowmi_sale_tton_gr } \sim \text { incost_coef_cowmi) }
$$

where cowmi_sale_tton_gr - annual rate of increase in milk sales (milk deliveries); incost_coef_cowmi - ratio of revenue to expense for milk production. 
By the application of the linear regression analysis (OLS) the intercept of the regression equation was obtained at -0.7263 , the coefficient for the predictor variable equalled 0.6212 , and $p=0.000$ (Table 1).

Table 1

Regression equation parameters for the ratio of revenue to expense for milk production in Latvia (2006-2016) $[19 ; 20]$

\begin{tabular}{|c|c|c|c|c|}
\hline \multicolumn{5}{|c|}{ Parameters of the regression equation } \\
\hline Ratios & Estimate & Std. Error & $t$ value & $\operatorname{Pr}(>|t|)$ \\
\hline Intercept & -0.7263 & 0.1456 & -4.988 & 0.000751 \\
\hline incost_coef_cowmi[y2006:y2016] & 0.6212 & 0.1168 & 5.320 & 0.000481 \\
\hline \multicolumn{5}{|c|}{ 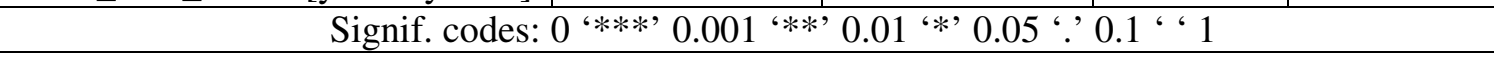 } \\
\hline $\begin{array}{l}\text { andard error: } 0.0 \\
R \text {-squared: } 0.73\end{array}$ & on 9 degr & freedom. M & & $\begin{array}{l}.7587, \\
809\end{array}$ \\
\hline
\end{tabular}

Future values of a ratio of revenue to expense for milk production needed for identifying the future annual rate of increase in milk sales were derived from the projections of the milk purchase price, support payments for milk production and milk production costs.

A projection of the milk purchase price for Latvia is based on medium-term projections of the average milk price in the EU for the period 2019-2030 made by the DG AGRI:

$$
\text { cowmi_price_pr }<- \text { cowmi_price_EU_pr * cowmi_price_conv_EU }
$$

where cowmi_price_pr-projected milk purchase price;

cowmi_price_EU_pr-average projected milk purchase price in the EU;

cowmi_price_conv_EU - convergence coefficient for the milk purchase price in Latvia.

Milk yield projection was generated in the model based on a logarithmic function with a milk yield target value of 10 tonnes per cow for 2050. The milk yield target value was based on an expert assessment that considered farm structural changes (increase in the size and production intensity) and genetic composition of dairy cow herds (increase in the proportion of Holstein cows that have higher milk yields). Milk yields are expected to increase more at the beginning of the projection period, as the milk yield changes presently occur faster.

The number of dairy cows is derived from the projections of total milk production and milk yield:

$$
\text { cowmi_thead_pr=cowmi_tton_pr / cowmi_yield_pr (5) }
$$

where cowmi_thead_pr-projected number of dairy cows;

cowmi_tton_pr - projected milk production;

cowmi_yield_pr - projected milk yield.

Number of dairy cows on various size farms. CSB data were used for a historical distribution of dairy cows by farm size.

A projection of the dairy cow number for farms with 1-2 cows was made by applying an annual decrease rate of $7 \%$.

A projection of the dairy cow number for farms with 3-49 cows was made by subtracting the projected number of dairy cows on farms of other sizes from the projected total number of dairy cows.

A projection of the dairy cow number for farms with 50-299 cows was assumed to be at the level of 2018.

A projection of the dairy cow number for farms with $\mathbf{3 0 0}$ and more cows was made based on the trend:

cowmi_thead_over300_reg $<-\operatorname{lm}$ (cowmi_thead_over300 cowmi_thead_over300_trend)

where cowmi_thead_over300 - number of dairy cows in the group of farms with 300 and more cows;

cowmi_thead_over300_trend-trend. 
The necessary parameters were derived from the linear regression analysis (OLS), where the intercept of the regression equation equalled 8.61007, the coefficient equalled 1.06595 and $p=0.000$ (Table 2).

Table 2

\section{Regression equation parameters for the number of farms with 300 and more cows in Latvia (2000-2018) [19; 20]}

\begin{tabular}{|c|c|c|c|c|}
\hline \multicolumn{5}{|c|}{ Parameters of the regression equation } \\
\hline Coefficients & Estimate & Std. Error & $t$ value & $\operatorname{Pr}(>|t|)$ \\
\hline Intercept & 8.61007 & 0.60961 & 14.12 & $8.01 \mathrm{e}-11$ \\
\hline cowmi_thead_over300_trend & 1.06595 & 0.05347 & 19.94 & $3.15 \mathrm{e}-13$ \\
\hline \multicolumn{5}{|c|}{ Signif. codes: 0 ‘***’ $0.001^{\prime} * * * 0.01$ ‘*’ $0.05^{\prime} \because 0.1$ ‘ 01} \\
\hline
\end{tabular}

\section{Results and discussion}

\section{Key characteristics of dairy farming}

The quantity of cow's milk produced in Latvia has gradually increased since 2005, reaching 983 thou. $\mathrm{t}$ in $2018(+21 \%)$. The most significant increase in milk production occurred between 2012 and 2014. Investments by large dairy farms and favourable milk market conditions during this period created a favourable environment for the development of large and highly productive farms. Milk production in 2018 has slightly exceeded the 1995 level $(+4 \%)$. However, in view of the historical milk production in the early 1990s, when almost 2 million tonnes of milk were produced in Latvia, the industry still has significant growth potential under favourable market conditions.

At the same time, the volume of milk sales for processing in Latvia has increased particularly significantly - it amounted to 781 thou. $t$ in 2018 , which was $56 \%$ more than in 2005 . In the last 20 years, milk sales to processing enterprises have more than doubled. However, it should be noted that the quantity of milk deliveries in 1990 was twice as high as in 2018 (1 611 thou. $t$ ).

The number of dairy cows in Latvia in 2018 was 144.5 thou., which was $22 \%$ less than in 2005. A particularly significant decrease in the number of dairy cows was observed between 2007 and 2009 and after 2014 (-13\% in 2018 compared with 2014). In both cases, the main reason for the decrease was changes in the market situation and decrease of milk prices (Fig. 1).

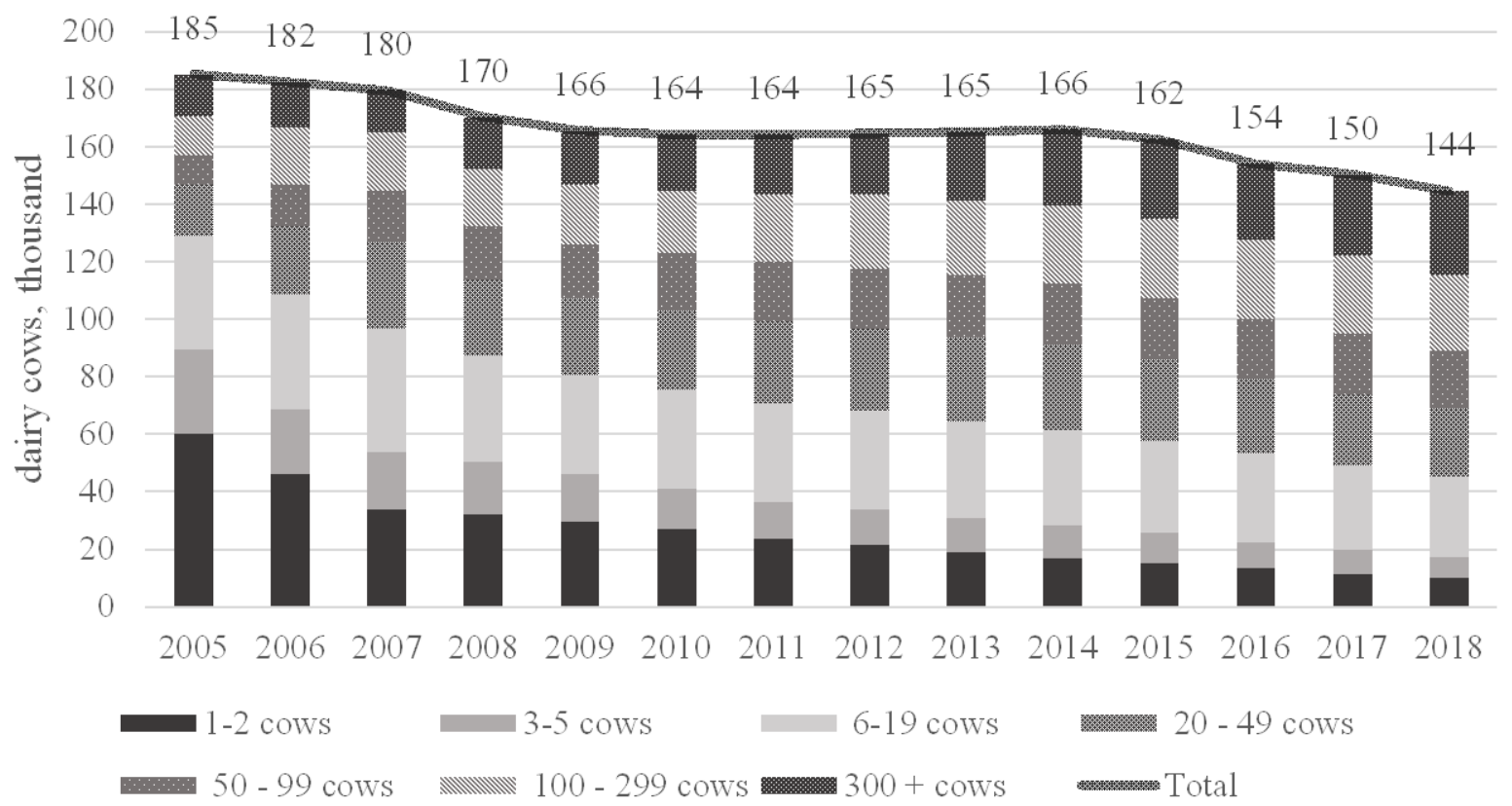

Fig. 1. Number of dairy cows by farm size group and the total in Latvia in 2005-2018, thou. [19; 20] 
The decrease in the number of cows was affected by the significant decrease in the number of small dairy farms. In total, the number of farms with up to 5 cows was 5.6-fold lower in 2018 than in 2005, yet the number of cows on these farms decreased 5.1-fold in 2018 compared with 2005 . The most significant decrease in the number of dairy cows was reported for the size group of farms with 12 dairy cows - from 60.3 thou. in 2005 to 9.9 thou. 2018 (6.1-fold). A similar situation was observed in the next farm size groups (3-5 and 6-19 cows) - the number of dairy cows decreased in these groups too, yet the decrease was less significant. The changes in the two smallest groups of farms were not linked with the milk price, so it could be concluded that the decrease in the number of cows was more affected by some other economic and social factors. In contrast, in all groups of farms with 20 or more cows, the number of cows has increased. The number of dairy cows has increased the most on farms with 100-199 cows (2.7-fold in 2018 compared with 2005) (Fig. 1).

The average milk yield in the country increased by $2250 \mathrm{~kg}(+52 \%)$ between 2005 and 2018 , while the average milk yield of supervised herds increased by $2496 \mathrm{~kg}(+49 \%)$, reaching $7580 \mathrm{~kg}$ in 2018.

The total number of dairy farms in Latvia has decreased significantly - from 59.6 thou. in 2005 to 13.8 thou. in 2018 (4.3-fold). The key reason was the significant decrease in the number of small farms - the number of farms with 1-2 and 3-5 cows decreased almost 6-fold and 4.1-fold, respectively. In contrast, the number of farms with 20 or more cows has increased by $44 \%$ over the last thirteen years (Fig. 2).

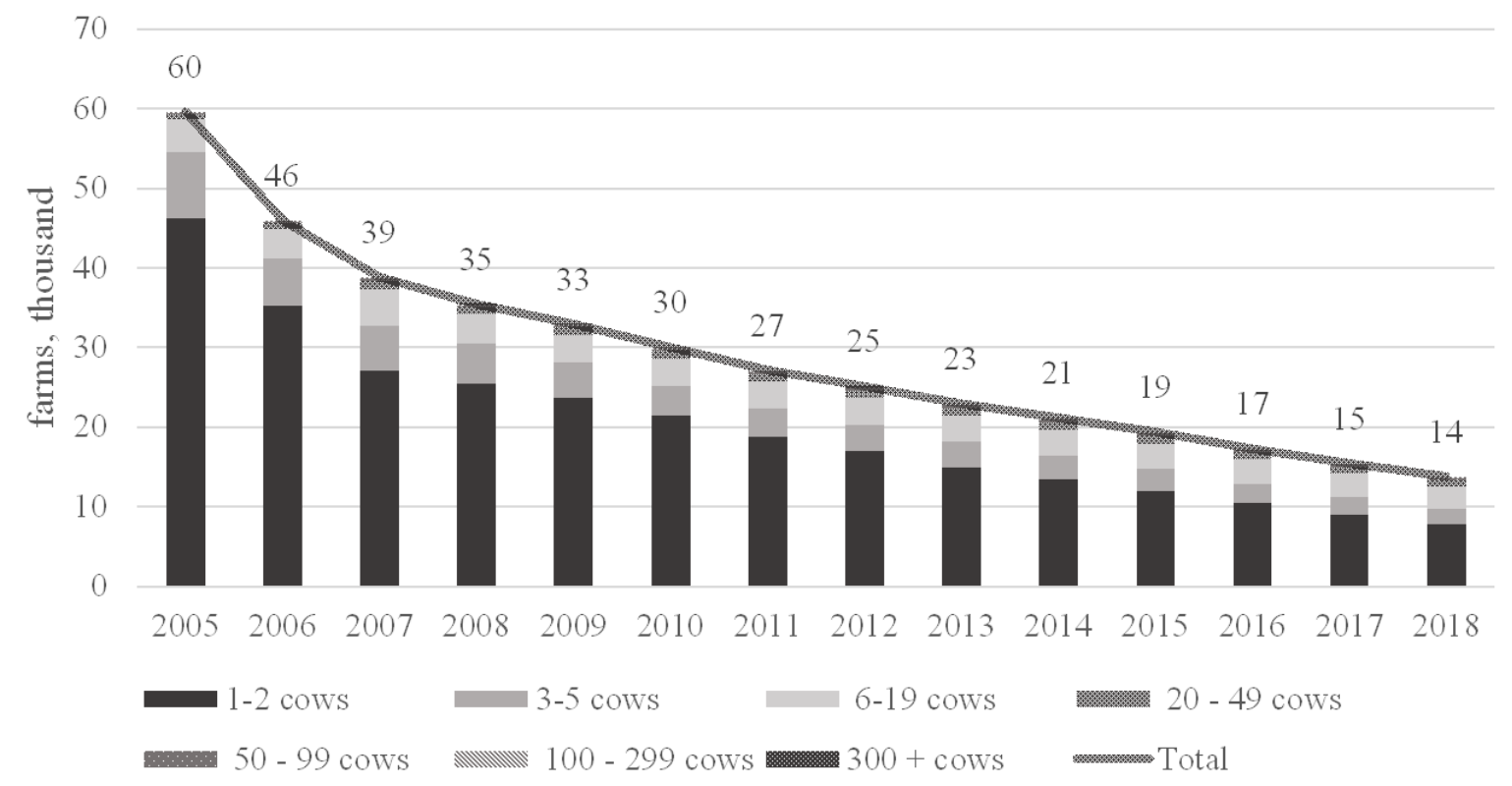

Fig. 2. Number of farms by size group in terms of the number of dairy cows and the total in Latvia in 2005-2018, thou. [19; 20]

The decrease in the number of small farms was affected by economic, technological and social factors. The main economic and technological factors were a decrease in farm competitiveness, technological obsolescence and changes in the requirements for milking and keeping cows, and for manure management. Dairy farming on small family farms is a traditional activity, yet it requires a lot of manual labour compared with other agricultural sectors. Therefore, as farm owners get older, abandoning this activity is a rational decision.

As the number of small farms decreases, the average number of dairy cows per dairy farm increases. Larger farms can provide good conditions for intensive dairy farming and increased milk yield. In 2018, there were, on average, 10.5 dairy cows per dairy farm, compared with 3.1 in 2005.

Overall, the trends point to the concentration of the dairy industry - small farms leave the market, whereas the most competitive farms continue growing and increasing their herds of cows. Considering the above-mentioned factors, as well as rising the labour costs and investment opportunities for large farms, it is expected that the group of large farms will continue to expand, whereas the number of small farms will continue to decrease. 
According to the CSB data for 2014, dairy farms with up to 10 cows contributed to only $20 \%$ of the total milk production, while the remaining $80 \%$ came from dairy farms with more than 10 cows.

Milk production is a sector characterized by rapid price changes and "crisis" stages, when the purchase price of milk decreases below the production cost of milk. These fluctuations have a particularly negative effect on the small group of farms, where according to the FADN data for 2018, the milk price was about $10 \%$ lower than that of large farms. The purchase price of milk in Latvia is closely related to the price of milk in the world and in the EU; therefore, global changes affect the local milk price and cause its fluctuations. The prices of milk in Lithuania and Estonia are similar, and the competitiveness of the Baltic States is determined by optimization of the milk production costs and the milk quantities processed. Overall, the dairy sectors of Lithuania and Estonia have experienced similar development trends as in Latvia - rising production in commercial farms, concentration and increasing milk yields. At the same time, the leader in total milk deliveries is Lithuania (about 1.4 million tonnes), while cows' productivity excels in Estonia (average milk yield was 9.3 tonnes per cow in 2018), which also has the largest dairy farms among the Baltic States [21].

\section{Development opportunities for dairy farms of various sizes in Latvia}

When projecting milk production (Fig.3), trends in three categories are taken into consideration commercial milk production for processing, farm self-consumption of milk for food and farm selfconsumption of milk for feed. Milk production is projected to increase gradually and stabilize by 2030. The key to the successful development of the industry is a favourable combination of prices, support policies and key production costs as well as the availability of forage areas. According to the projection (based on equations [1]-[4]), the production of milk in 2030 is going to increase to 1186.5 thou.t, while by 2050 the production is expected to increase to 1196.1 thou.t (22\% more than in 2018, when the production of milk reached 980.2 thou.t).

Milk yield is projected (Fig.4) to increase steadily to $8578 \mathrm{~kg}$ by 2030 and to $10000 \mathrm{~kg}$ by 2050 (+ $51 \%$ compared with 2018). This projection is affected by a number of factors, first of all, the intensification of production, choice of more productive breeds, and development of breeding, feeding and rearing technologies, which continue and will continue to contribute to increasing milk yields. Available EU funding for farm investment also contributes to intensification of production.

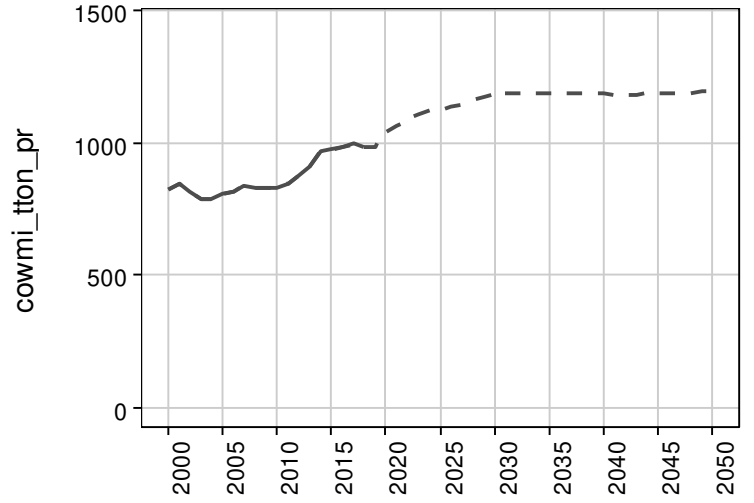

Fig. 3. Milk production in Latvia in 20002018 and a projection for 2019-2050, thou. $t[19 ; 20]$

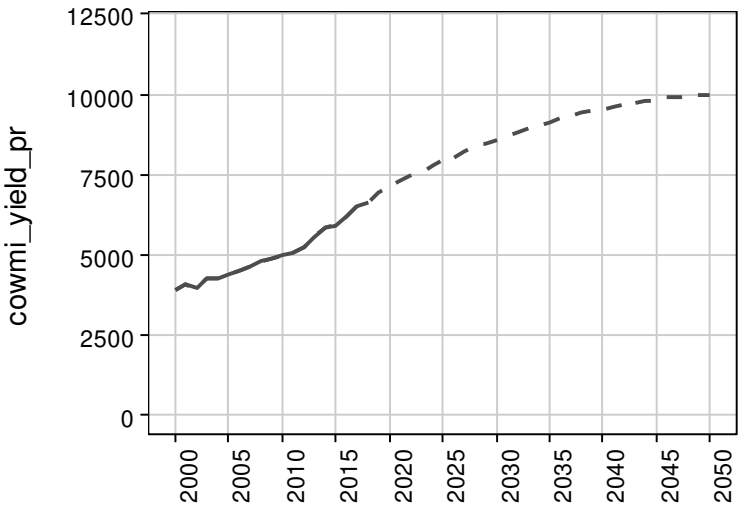

Fig. 4. Average milk yield per cow in Latvia in 2000-2018 and a projection for 2019-2050, $\mathrm{kg}^{-\operatorname{cow}^{-1}}$ per year $[19 ; 20]$

The average milk yield in the country is also affected by the composition of herds. Analysing the FADN data on milk yields broken down by farm size, significant differences could be observed among the farm size groups - milk yields are higher on large farms than on small ones -, which is due to the mentioned factors above. Consequently, as the number of small farms decreases and the large farms dominate the industry, the average milk yield is expected to increase in the country.

The number of dairy cows is expected to decrease gradually. By 2050, the number could decrease to 119.6 thou. cows, compared with 144.5 thou. in 2018 (-17\%). A slight increase in the number of cows is projected until 2022. 
The projections of the number of cows for various size farms (based on the methodology described above) vary. In accordance with the current trend in the number of cows, a decrease in the number of cows on small farms (with 1-2 and 3-49 cows) is projected up to 2050. On the smallest farms, the number of cows is projected to decrease from 9.9 thou. in 2018 to 4.1 thou. by 2030; however, by 2050, this group of farms is projected to have only 1 thou. cows (2.4-fold and 10.2-fold less than in 2018, respectively) (Fig. 5).

Farms with 3-49 cows are also projected to have a sharp decline in the number of cows. By 2030, the number of cows is expected to decrease by $21 \%$ (from 59.2 thou. to 46.4 thou.), yet by 2050, the number of cows in this group of farms is expected to be only about 9.5 thou. -6.2 -fold less than in 2018 (Fig. 6).

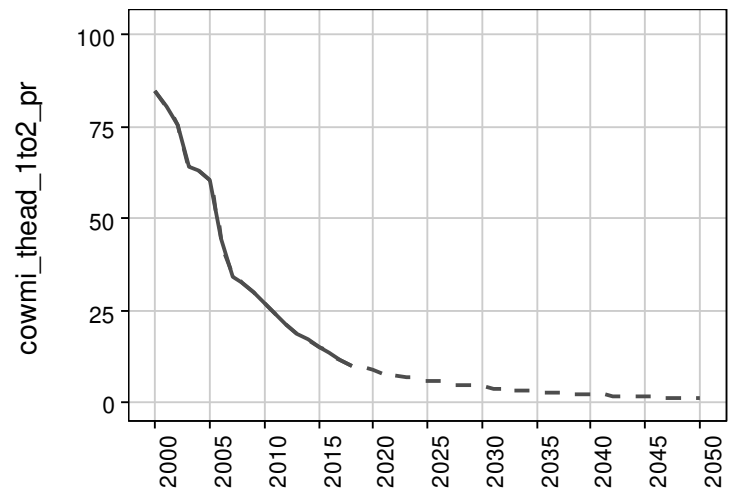

Fig. 5. Number of dairy cows in a group of farms with 1-2 cows in Latvia in 2000-2018 and a projection for 2019-2050, thou. [19; 20]

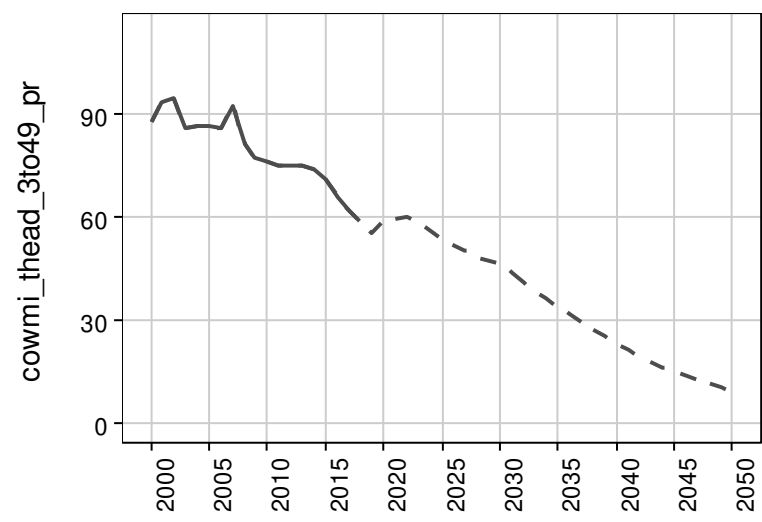

Fig. 6. Number of dairy cows in a group of farms with 3-49 cows in Latvia in 2000-2018 and a projection for 2019-2050, thou. [19; 20]

The number of cows on farms with 50-299 cows is projected to stabilize at the level of 2018 46.1 thou. cows (Fig.7). According to the projection (equation [6]), further production intensification and development of large farms are expected in the industry; therefore, the farms with more than 300 cows will continue growing. By 2030, the number of cows is projected to increase by $42 \%$, while by 2050 , the number of cows is expected to reach 63 thou., which is more than double the number in 2018 (29.2 thou.) (Fig.8). Accordingly, the future development of the dairy sector in Latvia is determined by the growth rates of farms with more than 300 cows.

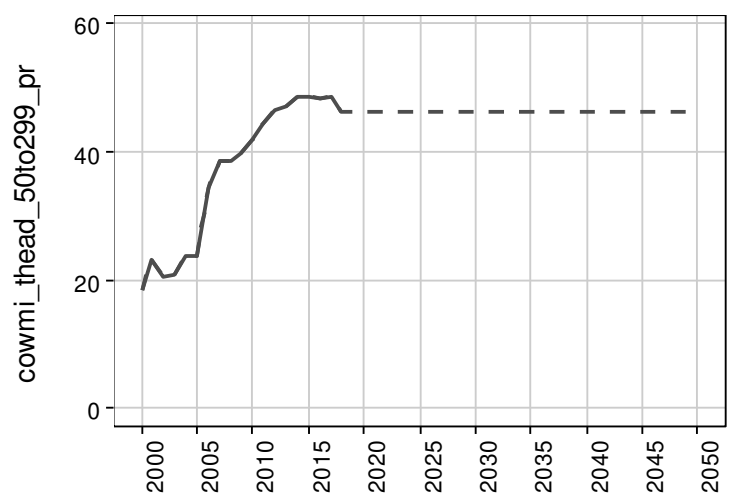

Fig. 7. Number of dairy cows in a group of farms with 50-299 cows in Latvia in 2000-2018 and a projection for 2019-2050, thou. [19; 20]

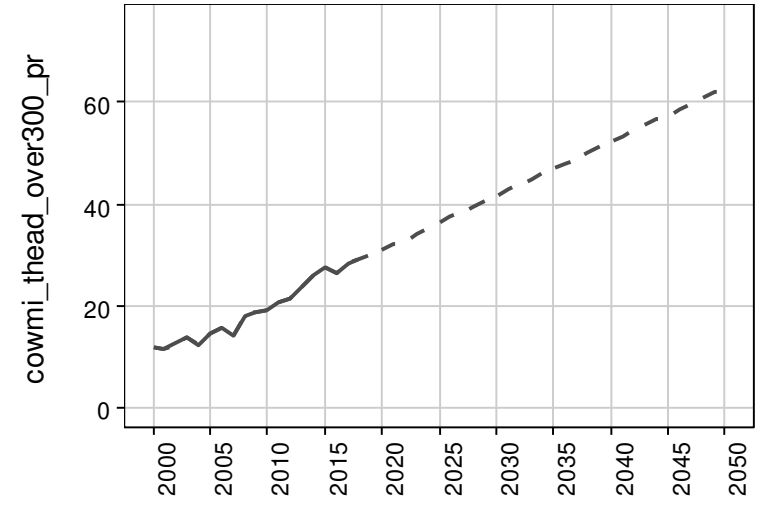

Fig. 8. Number of dairy cows in a group of farms with more than 300 cows in Latvia in 2000-2018 and a projection for 2019-2050, thou. [19; 20]

\section{Conclusions}

Significant structural changes in dairy farming were observed in Latvia during 2005-2018, as the production of cow's milk increased, reaching 983 thou. $t$ in 2018, and the sales of milk for processing reached 781 thou. $t$ in 2018, which was $56 \%$ more than in 2005. The number of dairy cows in Latvia 
in 2018 was 144.5 thou., which was $22 \%$ less than in 2005 . The decrease in the number of cows was affected by the significant decrease in the number of small dairy farms. The total number of dairy farms in Latvia has decreased significantly - from 59.6 thou. in 2005 to 13.8 thou. in 2018 (4.3-fold).

By 2050, the production of milk is projected to gradually increase to 1196.1 thou.t (22\% more than in 2018). The key to successful development of the industry is a favourable combination of prices, support policies and key production costs, as well as the availability of forage areas. In contrast, the number of dairy cows is expected to gradually decrease to 119.6 thou. (-17\% compared with 2018), which is determined by production intensification in dairy farming and the expansion of large farms with more than 300 cows.

\section{Acknowledgements}

The research was promoted with the support of the project of the Ministry of Agriculture of the Republic of Latvia "Forecasting of Agricultural Development and the Designing of Scenarios for Policies until 2050", agreement No. 19-00-SOINV05-000016.

\section{References}

[1] Helin J., Weikard H.P. A model for estimating phosphorus requirements of world food production. Agricultural Systems, Volume 176, November 2019, DOI: 10.1016/j.agsy.2019. 102666

[2] Bartosova A., Capell R., Olesen J.E., Jabloun M., Refsgaard J.Ch., Donnelly Ch., Hyytiäinen K., Pihlainen S., Zandersen M., Arheimer B. Future socioeconomic conditions may have a larger impact than climate change on nutrient loads to the Baltic Sea. Ambio 48, 2019, pp. 1325-1336. DOI: 10.1007/s13280-019-01243-5

[3] Yu W., Hertel Th., Preckel P., Eales J. Projecting World Food Demand Using Alternative Demand Systems. GTAP Working Paper No. 21 Published in: World Bank Economic Review 18(2), 2004, pp. 205-236.

[4] Galor O., Weil D.N. Population, Technology, and Growth: From Malthusian Stagnation to the Demographic Transition and Beyond. American Economic Review, 2000, 90, (4), pp. 806-828. DOI: $10.1257 /$ aer.90.4.806

[5] Odegard I., van der Voet E., The future of food -scenarios and the effect on natural resource use in agriculture in 2050. Ecol. Econ. 97, 2014, pp. 51-59. DOI: 10.1016/j.ecolecon.2013.10.005

[6] Duchin F. Sustainable consumption of food. A framework for analysing scenarios about changes in diets. Journal of Industrial Ecology, 9(1-2), 2005, pp. 99-114. DOI: $10.1162 / 1088198054084707$

[7] Nonhebel S. On resource use in food production systems. The value of livestock as 'rest-stream upgrading system'. Ecological Economics, 48(2), 2004, pp. 221-230. DOI: 10.1016/j.ecolecon.2003.09.013

[8] Yu W., Hertel T.W., Preckel P.V., Eales J.S. Projecting world food demand using alternative demand systems. Econ. Model. 21, 2003, pp. 99-129. [online][11.02.2020] Available at: https://www.gtap.agecon.purdue.edu/resources/download/2873.pdf

[9] Jones B., O'Neill B.C. Spatially explicit global population scenarios consistent with the Shared Socioeconomic Pathways. Environmental Research Letters, No. 11, 2016, 10 p. DOI: 10.1088/1748-9326/11/8/084003

[10] Meiyappan P., Dalton M., O'Neill B. C., Jain A. K. Spatial modeling of agricultural land use change at global scale. Ecological Modelling, No.291, 2014, pp. 152-174.

[11] Latvijas Republikas Zemkopības ministrija. Latvijas lauksaimniecība 2019 (Ministry of Agriculture. Agriculture in Latvia 2017). Riga, 2019, 188 p. (In Latvian).

[12] A. Johansson, Y. Guillemette, F. Murtin, D. Turner, G. Nicoletti, C. de la Maisonneuve, P. Bagnoli, G. Bousquet, F. Spinelli. Looking to 2060: Long-Term Global Growth Prospects. OECD, OECD Economic Policy Papers No.03, Paris, November 2012, 30 p.

[13] De Pue D., Bral A., Buysse J. Abatement of ammonia emissions from livestock housing finetuned according to impact on protected habitats. Agricultural Systems No.176, 2019, DOI: 10.1016/j.agsy.2019.102667 
[14] Helin, J., Reducing nutrient loads from dairy farms: a bioeconomic model with endogenous feeding and land use. J. Agric. Econ. 45, 2014. pp. 167-184. DOI: 10.1111/agec.12039

[15] Gerbens-Leenes P., Nonhebel S., Krol M., Food consumption patterns and economic growth. Increasing affluence and the use of natural resources. Appetite 55, 2010, pp. 597-608. DOI: 10.1016/j.appet.2010.09.013

[16] Nipers A., Pilvere I., Zeverte-Rivza S., Krievina A. Use of Econometric Model for Developing an Outlook for Livestock Sector in Latvia In: 16th International Scientific Conference "Engineering for Rural Development": Proceedings, May 24-26, 2017, vol. 16, Jelgava, Latvia, pp. 874-883. DOI: 10.22616/ERDev2017.16.N176.

[17] Nipers A., Pilvere I., Zeverte-Rivza S. Projections for the Latvian Dairy and Beef Sector. In: 16th International Scientific Conference "Engineering for Rural Development": Proceedings, May 2426, 2017, vol. 16, Jelgava, Latvia, pp. 546-554. DOI: 10.22616/ERDev2017.

[18] Nipers A., Pilvere I., Zeverte-Rivza S., Upite I., Krievina A. Projections for the Latvian Cereal Sector. In: 17th International Multidisciplinary Scientific GeoConference SGEM 2017, Vienna GREEN Conference Proceedings, 27-29 November, 2017, vol. 17, issue 63, pp. 309-318. DOI: $10.5593 /$ sgem 2017H/63/S25.040.

[19]Zinātniskā pētījuma Lauksaimniecības attīstības prognozēšana un politikas scenāriju izstrāde līdz 2050. gadam projekta atskaite (Report on the Project Forecasting of Agricultural Development and the Designing of Scenarios for Policies until 2050). Jelgava: Latvia University of Agriculture, November 2019, 163 p. (In Latvian).

[20] SUDAT datu bāze (FADN database). Unpublished resource. (In Latvian).

[21] Agriculture, forestry and fisheries: Eurostat database. [online][11.02.2020] Available at: https://ec.europa.eu/eurostat/home? 